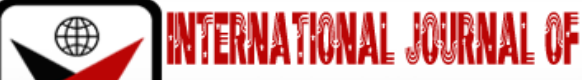

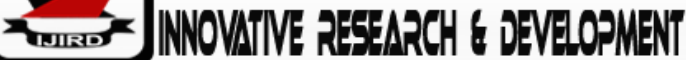

ISSN 2278-0211 (Online)

\section{School Library Resources Usage in a Faith-Based Secondary School}

\author{
F. A. Ojo \\ School Librarian, School Library, \\ The Apostolic Model College, Sango, Ibadan, Nigeria \\ o. Osunade \\ Associate Professor, Department of Computer Science, \\ University of Ibadan, Nigeria
}

\begin{abstract}
:
A school library advances the course of education and is made up of resources such as books, learning aids, audiovisual and serial publications. The ownership of a school library requires huge investments in physical, human and material resources. Many schools are unable to justify the investment due to lack of data on library usage and access to library resources. This work seeks to provide information on library resource use by students in a faith-based secondary school. The data was collected from attendance register and library inventory. Simple statistical analysis was carried out on the data. Results indicate that the day of the week does not affect use of library resources. There is also the need for a variety of library resources because the reading pattern of the students changes every week.
\end{abstract}

Keywords: School library, resource, faith-based organization, Nigeria

\section{Background}

Libraries are institutions saddled with the responsibility of providing relevant documents and publications to users. The five types of libraries based on the type of users are: national, academic, public, special and school libraries (Uzuegbu and Ibiyemi, 2013). According to Aina (2004) stated that the school library is attached to schools such as preprimary, primary and secondary schools and is meant to supplement classroom teaching of school children. A school library should contain materials that would interest both students and teachers. Materials expected in a school library include books, magazines, periodicals, newspapers, atlas, encyclopedia, dictionaries, maps, pictures and tapes. Infrastructure such as whiteboard, television with video (VHS/CD/VCD/DVD) player and computer system can also be incorporated. A professionally trained librarian called School or Teacher Librarian is expected to manage the school library. David-West and Bassey (2017) identified the need for advocacy to promote the establishment, maintenance and management of school libraries. The study provided useful approaches to advocacy for the sustenance of school libraries. The Apostolic Church Model College, Ibadan is a secondary education institution owned by The Apostolic Church of Sango, Eleyele in Ibadan North East Local Government Area of Ibadan, Oyo State. The College was established on 12 November 2007. It maintains a social media presence on Facebook that is available at https://www.facebook.com/tacmcofficial/. The school library started after the establishment of the school and a trained librarian had always been employed to manage the affairs. The school library is situated at the entrance of the school premises. The school management have made investments into the school library, but require evidence that additional investment is justified. The aim of this study therefore is to examine the school library resources available to students and their use by students in a faith-based secondary school.

\section{Related Works}

Studies have been carried out on the use and significance of school library to students and teachers in form of utilization, materials available and academic motivation. A few of those studies in Nigeria are discussed in this section.

The school library at Item Community High School of Abia State, Nigeria was examined for its significance to the school by Uzuegbu and Ibiyemi (2013). The study found out that the school library had been shut for one year due to non-availability of a qualified personnel. The facility provision at the designated school library had 25 chairs and tables, 3 shelves and 10 windows. The inventory of the materials listed seven hundred and thirty-one textbooks, four journals, twenty-seven pamphlets, seven reference materials (encyclopedia, maps and atlas). The materials are not related to the school curriculum. There are 166 users of the school library i.e., 10 teachers, 149 students and 7 corp members. The need for a Teacher Librarian, learning materials and materials appropriate for the target audience are important extracts from this study. 
Akande and Bamise (2017) examined the role of school library as a motivation for academic performance of secondary school students in Osun State. Students surveyed were from two secondary schools selected from three local governments within a senatorial district. The results indicated reduction in library use compared to other states in Nigeria, more boys use the library than girls, reading textbooks was the reason for using the library and using the library as a private place to study. The library resources available are limited to text. The study did not however link the use of the school library to academic performance of the students.

Twenty secondary schools were studied by Zaid (2004) in Lagos State of Nigeria. The study reported the presence of a school library in all the secondary schools examined with card or book catalogue in use. The book collections available by the secondary schools were classified as non-fiction, fiction, reference books and periodicals. The non-fiction category had a larger percentage of the materials in most of the secondary schools. Only eight schools had trained library personnel, while the other schools used graduates without training or clerical assistants. The use of computers for library services was available at eleven secondary schools while only four provided Internet-based services. In this study, private and public secondary schools were used thus providing an indication that funding is crucial to providing library services. Employment of qualified librarian should be encouraged by secondary school boards.

Lawal-Solarin (2016) investigated the school library of six private secondary schools in Ogun State on impact of the school library. About half of the students reported asking the librarian for assistance to locate a resource. A large percentage of the students were not satisfied with the resources available in the school library. Three schools had qualified library staff while three schools used students to manage the school library. The use of school library is affected by the quality of materials, library personnel and ease of locating resources. Another study in Ogun State, Nigeria by Bamidele (2015) looked at the library use habits of senior secondary schools in three selected secondary schools from each of three senatorial districts in the state. There were more female students than male students. Over $80 \%$ of the students had a library in their school and had used the library. About half of the students required no motivation to use the library even though it was not listed on the timetable. A large number of students try to use all the library facilities, borrow books and consult the library staff in the school library. The study has identified library use habits among senior secondary school students without relating it to the demographic data of the students or the environment. Adebamowo (2011) reported his findings from selected secondary schools in Ijebu North Local Government Area of Ogun State, Nigeria. The six secondary schools investigated had materials like dictionaries, encyclopedia, yearbooks, maps, atlases, textbooks and magazines with no audio-visual material. Students mainly came to read personal books in the school library followed by borrowing books. In five out of six schools, a classroom was converted to be the school library. There was no professionally trained librarian in all the school, but teachers were given the additional responsibility. The recommendations given are appropriate for the growth and development of a school library.

In Ondo State, Nigeria Daramola (2013) used ten secondary schools to study the use, available facilities, challenges and presence of a school library. All the secondary schools had a school library with students knowing the location. Reading was the major reason for using the school library by students. The presence of library furniture and resources such as textbooks, newspaper, periodicals and reference books were confirmed by the students. Challenges identified by the students include lack of audio-visual materials, lack of Internet facilities, lack of qualified staff and improper use of the school library. The data for the ten secondary schools was jointly analyzed thus anomalies could not be identified for further study.

A study carried out in Akinyele Local Government Area of Oyo State by Moruf (2015) investigated the utilization of school library by students in four selected secondary schools. The school librarians were not professionally trained. The school libraries had textbooks, reference materials, newspapers/magazines, computers but no audio-visual materials. The students identified guidance on using the library, lending and borrowing books and assistance to secure materials as the services provided by the school library. Limited space for users of the library, materials not up to date and materials not well organized were some of the problems listed by the students. The mean of responses to frequency of school library use was below the average mark indicating that students do not use the school library. This study done close to the location of the current study is exploratory and can be used as a baseline for studies in Oyo State, Nigeria

\section{Methodology}

This study was carried out using observation method using primary data to determine how students use library resources in a faith-based secondary school in Ibadan, Oyo State. The Apostolic Church Model College, Ibadan was used as the case study. The population of the study consisted of all the students in the school i.e., Junior and Senior secondary classes. The primary data was collected over a four-week period (i.e., 21 October 2019 to 15 November 2019). Simple statistical analysis was used for data analysis.

\section{Results and Discussion}

The following results were obtained using simple statistical methods such as frequency and percentages. 


\begin{tabular}{|c|c|c|c|}
\hline Class & \multicolumn{3}{|c|}{ Number } \\
\hline & Male & Female & Total \\
\hline JS 1 & 61 & 35 & 96 \\
\hline JS 2 & 60 & 46 & 106 \\
\hline JS 3 & 30 & 30 & 60 \\
\hline SS 1 & 43 & 30 & 73 \\
\hline SS 2 & 29 & 38 & 67 \\
\hline SS 3 & 24 & 24 & 48 \\
\hline Total & 247 & 203 & 450 \\
\hline
\end{tabular}

Table 1: Number and Gender of Students

In Table 1, the distribution of students by classes is provided. JS 2 has the highest number of students while SS 3 has the lowest number. There are more male students those female students. The student population is 450 .

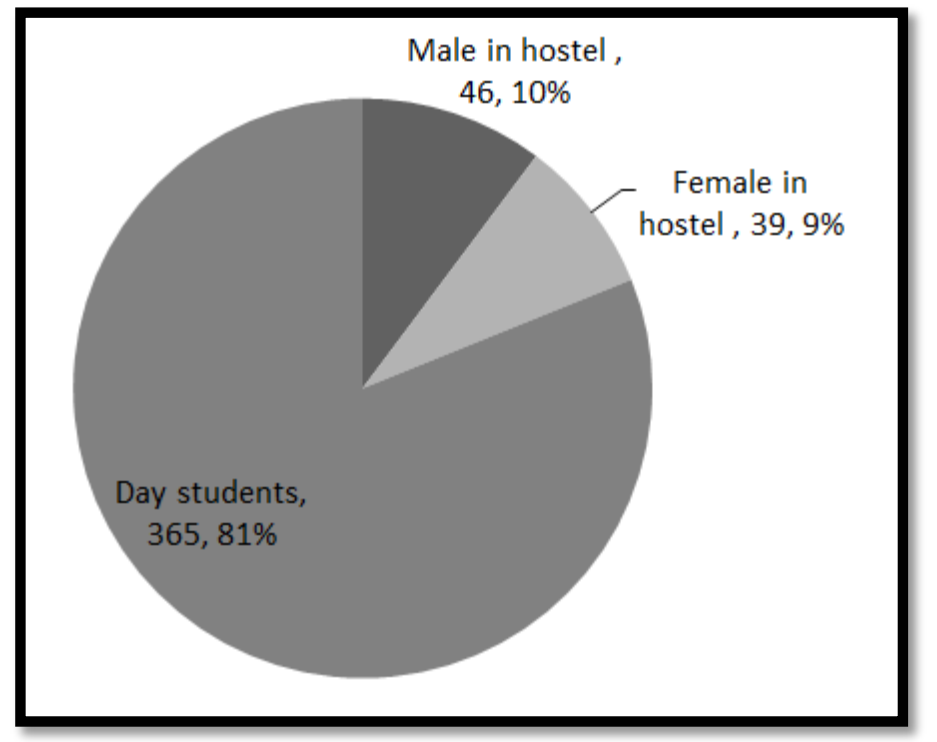

Figure 1: Student Accommodation

The school has boarding facilities for students. Figure 1 shows that $19 \%$ of the students stay in the hostel or boarding facilities while $81 \%$ come from home i.e., day students.

\begin{tabular}{|c|c|}
\hline Item & Frequency \\
\hline Separate building & 1 \\
\hline Number of Chairs & 40 \\
\hline Library Staff & 1 \\
\hline
\end{tabular}

Table 2: Library Accommodation

Table 2 shows that the school library has capacity to take 40 students with 40 chairs available. There is a separate building and qualified staff for the school library. 


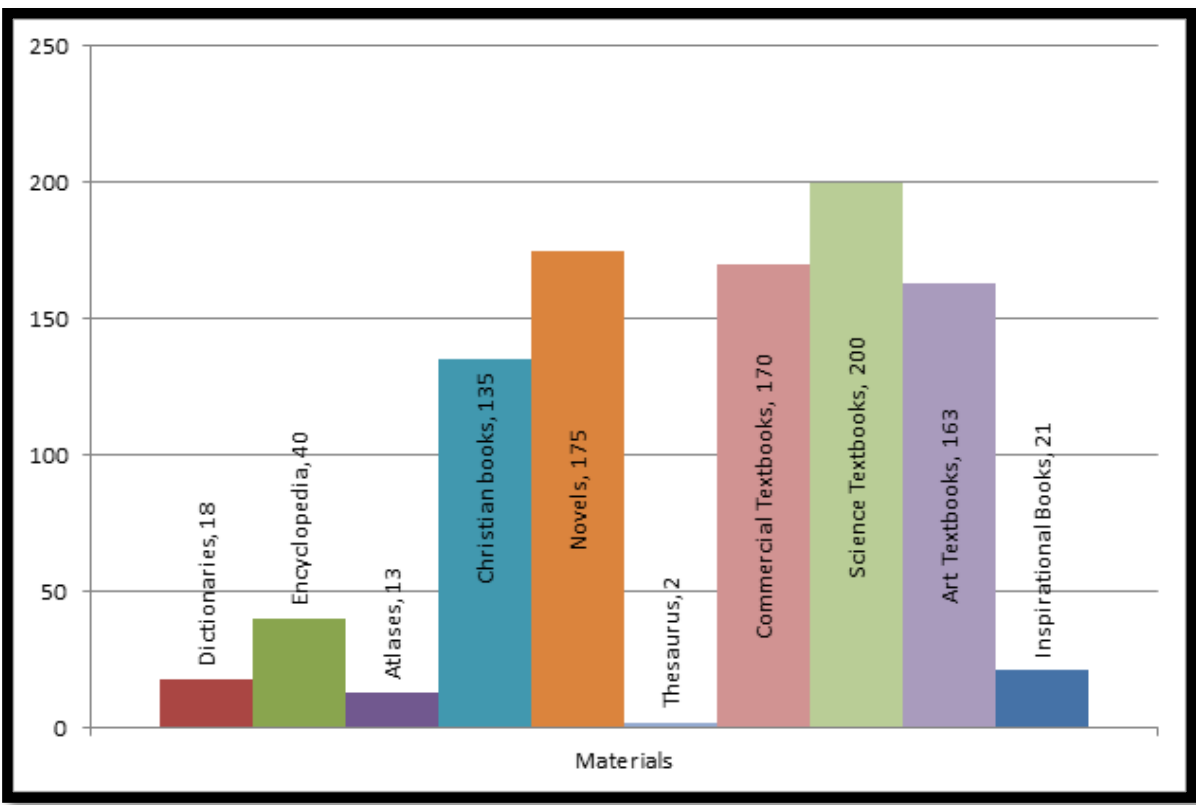

Figure 2: Materials in the School Library

The bar chart in Figure 2 shows that the school library is made up mainly of science, commercial and art textbooks. Faith-based materials available include Christian books and inspirational books. Reference materials available include dictionaries, encyclopedia, atlas and thesaurus.

\begin{tabular}{|c|c|c|}
\hline Materials & Frequency & Percentage \\
\hline Dictionaries & 18 & 1.9 \\
\hline Encyclopedia & 40 & 4.3 \\
\hline Atlases & 13 & 1.4 \\
\hline Christian books & 135 & 14.4 \\
\hline Novels & 175 & 18.7 \\
\hline Thesaurus & 2 & 0.2 \\
\hline Commercial Textbooks & 170 & 18.1 \\
\hline Science Textbooks & 200 & 21.3 \\
\hline Art Textbooks & 163 & 17.4 \\
\hline Punch Newspaper & $*$ & $*$ \\
\hline Inspirational Books & 21 & 2.2 \\
\hline Total & 937 & 100 \\
\hline
\end{tabular}

Table 3: Materials in School Library

Table 3 shows that the school library collection has 56\%textbooks for Commercial, Science and Arts. The library stock consists of $7 \%$ reference materials, Christian books add up to $14 \%$, novels are $18.7 \%$ and inspirational books are $2.2 \%$. The school subscribes to the Punch Newspaper thus there are unlimited number of issues.

\subsection{Student use of the School Library}

\begin{tabular}{|c|c|c|c|c|c|c|c|}
\hline CLASS & Mon & Tue & Wed & Thurs & Fri & Frequency & Percentage \\
\hline JS 1 & - & - & - & - & 1 & 1 & 0.5 \\
\hline JS 2 & 15 & 2 & 16 & 9 & 10 & 52 & 24 \\
\hline JS 3 & - & 31 & 1 & 2 & 2 & 36 & 17 \\
\hline SS 1 & 1 & 7 & 13 & 5 & 3 & 29 & 14 \\
\hline SS 2 & 23 & 12 & 4 & 9 & 15 & 63 & 29.5 \\
\hline SS 3 & 10 & 2 & 3 & 8 & 9 & 32 & 15 \\
\hline TOTAL & 49 & 54 & 37 & 33 & 40 & 213 & 100 \\
\hline
\end{tabular}

Table 4: Attendance Frequency for Week 1

Table 4 shows that in the first week SS 2 had 29.5\% attendance which was the highest attendance while JS 1 had $0.5 \%$ as the lowest attendance for the first week. 


\begin{tabular}{|c|c|c|c|c|c|c|c|}
\hline CLASS & Mon & Tue & Wed & Thurs & Fri & Frequency & Percentage \\
\hline JS 1 & - & - & 6 & 2 & 5 & 13 & 6.3 \\
\hline JS 2 & 24 & - & 20 & 6 & 5 & 55 & 26 \\
\hline JS 3 & 1 & 9 & - & 4 & 10 & 24 & 12 \\
\hline SS 1 & 2 & 10 & 12 & 2 & 3 & 29 & 14 \\
\hline SS 2 & 12 & 8 & 12 & 10 & 2 & 44 & 21 \\
\hline SS 3 & 8 & 7 & 5 & 19 & 5 & 44 & 21 \\
\hline TOTAL & 47 & 34 & 55 & 40 & 30 & 209 & 100 \\
\hline
\end{tabular}

Table 5: Attendance Frequency for Week 2

Table 5 shows that in the second week JS 2 had $26 \%$ which was the highest attendance while JS1 had $6.3 \%$ as the lowest attendance for the second week.

\begin{tabular}{|c|c|c|c|c|c|c|c|}
\hline CLASS & Mon & Tue & Wed & Thurs & Fri & Frequency & Percentage \\
\hline JS 1 & - & 2 & - & 30 & 45 & 77 & 30 \\
\hline JS 2 & 24 & 3 & - & - & 9 & 36 & 14.2 \\
\hline JS 3 & - & 35 & - & - & 6 & 41 & 16 \\
\hline SS 1 & 4 & 2 & 5 & 3 & 17 & 31 & 12 \\
\hline SS 2 & 10 & 4 & 22 & 9 & 3 & 48 & 19 \\
\hline SS 3 & 5 & 8 & 3 & - & 5 & 21 & 8.3 \\
\hline TOTAL & 43 & 54 & 30 & 42 & 85 & 254 & 100 \\
\hline
\end{tabular}

Table 6: Attendance Frequency for Week 3

Table 6 shows that in the third week JS 1 ha 30\% which is the highest attendance while SS 3 has $8 \%$ as the lowest attendance.

\begin{tabular}{|c|c|c|c|c|c|c|c|}
\hline CLASS & Mon & Tue & Wed & Thurs & Fri & Frequency & Percentage \\
\hline JS 1 & 1 & - & 1 & 3 & 5 & 10 & 4.3 \\
\hline JS 2 & 2 & - & 2 & 2 & 5 & 11 & 5 \\
\hline JS 3 & 15 & 32 & 2 & 8 & 4 & 61 & 26 \\
\hline SS 1 & 19 & 6 & 10 & 1 & 14 & 50 & 21 \\
\hline SS 2 & 8 & 5 & 8 & 13 & 4 & 38 & 16 \\
\hline SS 3 & 23 & 9 & 13 & 4 & 14 & 63 & 27 \\
\hline TOTAL & 68 & 52 & 36 & 31 & 46 & 233 & 100 \\
\hline
\end{tabular}

Table 7: Attendance Frequency for Week 4

Table 7 shows that in the fourth week SS 3 had 27\% which is the highest attendance while JS 1 has $4.3 \%$ as the lowest attendance. The attendance of JS 3 is close to that of SS 3.

\subsection{Use of School Library Materials by Students}

\begin{tabular}{|c|c|c|c|c|c|c|c|}
\hline Item & Mon & Tue & Wed & Thurs & Fri & Frequency & Percentage \\
\hline Dictionaries & - & - & 1 & - & - & 1 & 0.5 \\
\hline Encyclopedia & - & - & - & - & - & - & - \\
\hline Atlases & - & - & - & - & - & - & - \\
\hline Newspaper & 2 & 4 & 6 & 7 & 4 & 23 & 11 \\
\hline Novels & 15 & 2 & 1 & - & - & 18 & 8.5 \\
\hline Reading notes & 18 & 30 & 24 & 17 & 33 & 122 & 57 \\
\hline Christian books & - & 1 & - & 2 & - & 3 & 1.5 \\
\hline Commercial textbooks & 2 & 4 & 2 & 2 & 2 & 12 & 5.6 \\
\hline Science textbooks & 11 & 5 & 3 & 4 & 2 & 25 & 12 \\
\hline Art textbooks & 1 & 5 & - & 2 & 1 & 9 & 4 \\
\hline Total & 49 & 51 & 37 & 34 & 42 & 213 & 100 \\
\hline
\end{tabular}

Table 8: Materials used by Students in Week 1

Table 8 shows that $21.5 \%$ of the students make use of their subject textbooks (Commercial, Art and Science textbooks) while $0.5 \%$ make use of dictionaries. Class notes are read by $57 \%$ of the students in the library. 


\begin{tabular}{|c|c|c|c|c|c|c|c|}
\hline Item & Mon & Tue & Wed & Thurs & Fri & Frequency & Percentage \\
\hline Dictionaries & 2 & 1 & 1 & 2 & 5 & 11 & 5.3 \\
\hline Encyclopedia & - & 1 & 1 & 2 & 2 & 6 & 3 \\
\hline Atlases & - & - & 2 & 1 & 2 & 5 & 2.4 \\
\hline Newspaper & 5 & 3 & 6 & 5 & 4 & 23 & 11.5 \\
\hline $\begin{array}{c}\text { Commercial } \\
\text { textbooks }\end{array}$ & 2 & - & 3 & 1 & 4 & 10 & 1 \\
\hline $\begin{array}{c}\text { Science } \\
\text { textbooks }\end{array}$ & 1 & - & 9 & 4 & 5 & 19 & 10 \\
\hline Art textbooks & - & - & 4 & 1 & 3 & 8 & 4 \\
\hline Class notes & 15 & - & - & 1 & - & 16 & 3 \\
\hline $\begin{array}{c}\text { Christian } \\
\text { books }\end{array}$ & - & - & 2 & 3 & 1 & 6 & 3 \\
\hline Novels & 22 & 29 & 29 & 20 & 5 & 105 & 50 \\
\hline TOTAL & 47 & 34 & 57 & 40 & 31 & 209 & 100 \\
\hline
\end{tabular}

Table 9: Materials Used by Students in Week 2

Table 9 shows that $50 \%$ of the students read novels while $1 \%$ make use of commercial textbooks as the lowest usage for the second week.

\begin{tabular}{|c|c|c|c|c|c|c|c|}
\hline Materials & Mon & Tue & Wed & Thurs & Fri & Frequency & Percentage \\
\hline Dictionaries & 1 & 2 & 2 & - & 3 & 8 & 3 \\
\hline Encyclopedia & - & - & 2 & - & 2 & 4 & 2 \\
\hline Atlases & - & - & 2 & 1 & 1 & 4 & 2 \\
\hline Newspaper & 3 & 3 & 5 & 2 & 3 & 16 & 6 \\
\hline $\begin{array}{c}\text { Commercial } \\
\text { textbooks }\end{array}$ & 3 & 4 & 2 & 2 & 2 & 13 & 5 \\
\hline Science textbooks & 1 & 6 & 4 & 6 & 8 & 25 & 10 \\
\hline Art textbooks & 1 & 5 & 1 & 1 & 2 & 10 & 4 \\
\hline Class notes & 8 & 34 & 4 & 6 & 8 & 60 & 24 \\
\hline Christian books & - & - & - & - & 2 & 2 & 1 \\
\hline Novels & 26 & - & 8 & 24 & 54 & 112 & 44 \\
\hline TOTAL & 43 & 54 & 30 & 42 & 85 & 254 & 100 \\
\hline
\end{tabular}

Table 10: Materials Used by Students in Week 3

Table 10 shows that the $44 \%$ of the students make use of the novels while $1 \%$ make use of Christian books as the lowest usage for week three.

\begin{tabular}{|c|c|c|c|c|c|c|c|}
\hline Materials & Mon & Tue & Wed & Thurs & Fri & Frequency & Percentage \\
\hline Dictionaries & 2 & 2 & 2 & 1 & 2 & 9 & 4 \\
\hline Encyclopedia & 1 & 1 & 1 & - & 2 & 5 & 2 \\
\hline Atlases & 1 & - & 1 & - & 1 & 3 & 1 \\
\hline Newspaper & 4 & 4 & 3 & 2 & 2 & 15 & 6 \\
\hline $\begin{array}{c}\text { Commercial } \\
\text { textbooks }\end{array}$ & 5 & 1 & 2 & - & 1 & 9 & 4 \\
\hline Science textbooks & 8 & 10 & 6 & 6 & 6 & 36 & 16 \\
\hline Art textbooks & 5 & 5 & 2 & 1 & 4 & 17 & 7 \\
\hline Class notes & 1 & 7 & 6 & 6 & 10 & 30 & 13 \\
\hline Christian books & 2 & 2 & 1 & 2 & 2 & 9 & 4 \\
\hline Novels & 39 & 20 & 12 & 13 & 16 & 100 & 43 \\
\hline Total & 68 & 52 & 36 & 31 & 46 & 233 & 100 \\
\hline
\end{tabular}

Table 11: Materials Used by Students in Week 4

Table 11 shows that $43 \%$ of the students made use of novels while $1 \%$ made use of Atlases as the lowest usage for week four. There were 68 materials used on Monday and 31 materials used on Thursday. 


\subsection{Reason for Using School Library}

\begin{tabular}{|c|c|c|c|c|c|c|c|}
\hline Date & Mon & Tue & Wed & Thurs & Fri & Frequency & Percentage \\
\hline $\begin{array}{c}\text { To read } \\
\text { newspaper }\end{array}$ & 2 & 5 & 6 & 8 & 4 & 25 & 12 \\
\hline To borrow books & 1 & 2 & - & 1 & 4 & 8 & 4 \\
\hline $\begin{array}{c}\text { Browse through } \\
\text { collections }\end{array}$ & - & 2 & 1 & - & 1 & 4 & 2 \\
\hline $\begin{array}{c}\text { To read personal } \\
\text { books }\end{array}$ & 18 & 30 & 24 & 17 & 20 & 109 & 51 \\
\hline $\begin{array}{c}\text { To do } \\
\text { assignment }\end{array}$ & - & - & - & - & - & - & 31 \\
\hline $\begin{array}{c}\text { To read library } \\
\text { textbooks }\end{array}$ & 29 & 17 & 6 & 10 & 5 & 67 & 100 \\
\hline Total & 50 & 56 & 37 & 36 & 34 & 213 & - \\
\hline
\end{tabular}

Table 12: Purpose of Using the School Library in Week 1

Table 12 shows that how 51\% of students use the library to read personal books, while $12 \%$ use the library to read newspaper. $4 \%$ borrow books from the library, while $2 \%$ browse through the collection without borrowing for the week. The library is used by $31 \%$ of the students for reading library textbooks.

\begin{tabular}{|c|c|c|c|c|c|c|c|}
\hline Purpose & Mon & Tue & Wed & Thurs & Fri & Frequency & Percentage \\
\hline To read newspaper & 5 & 3 & 6 & 5 & 4 & 23 & 11 \\
\hline To borrow books & 6 & 1 & 4 & 2 & - & 13 & 6 \\
\hline $\begin{array}{c}\text { Browse through } \\
\text { collections }\end{array}$ & 2 & - & - & 5 & 3 & 6 & 3 \\
\hline $\begin{array}{c}\text { To read personal } \\
\text { books }\end{array}$ & 15 & - & - & 1 & - & 16 & 6 \\
\hline To do assignment & - & - & 3 & 6 & 5 & 12 & 67 \\
\hline $\begin{array}{c}\text { To read library } \\
\text { textbooks }\end{array}$ & 25 & 31 & 46 & 23 & 18 & 139 & 100 \\
\hline Total & 53 & 35 & 59 & 42 & 30 & 209 & \\
\hline
\end{tabular}

Table 13: Purpose of Using the School Library in Week 2

Table 13 shows that $67 \%$ of students use the library to read library books, while $11 \%$ use the library to read newspaper. $6 \%$ borrow books from the library, while $6 \%$ browse through the collection without borrowing for the week.

\begin{tabular}{|c|c|c|c|c|c|c|c|}
\hline Purpose & Mon & Tue & Wed & Thurs & Fri & Frequency & Percentage \\
\hline $\begin{array}{c}\text { To read } \\
\text { newspaper }\end{array}$ & 3 & 3 & 5 & 2 & 3 & 16 & 6 \\
\hline To borrow books & - & 4 & 2 & 2 & 1 & 9 & 4 \\
\hline $\begin{array}{c}\text { Browse through } \\
\text { collections }\end{array}$ & - & - & - & - & - & - & 21 \\
\hline $\begin{array}{c}\text { To read personal } \\
\text { books }\end{array}$ & 8 & 34 & 4 & 6 & 8 & 54 & 63 \\
\hline $\begin{array}{c}\text { To do } \\
\text { assignment }\end{array}$ & - & 6 & 2 & 1 & 6 & 15 & 100 \\
\hline $\begin{array}{c}\text { To read library } \\
\text { textbooks }\end{array}$ & 32 & 11 & 19 & 33 & 68 & 160 & 634 \\
\hline Total & 43 & 52 & 32 & 41 & 86 & 254 & \\
\hline
\end{tabular}

Table 14: Purpose of Using the School Library in Week 3

Table 14 shows that $63 \%$ of students use the library to read library books, while $6 \%$ use the library to read newspaper. $4 \%$ borrow books from the library, while $21 \%$ read personal books for the week. 


\begin{tabular}{|c|c|c|c|c|c|c|c|}
\hline Purpose & Mon & Tue & Wed & Thurs & Fri & Frequency & Percentage \\
\hline To read newspaper & 4 & 4 & 3 & 2 & 2 & 15 & 6 \\
\hline To borrow books & - & - & 1 & - & 5 & 6 & 3 \\
\hline $\begin{array}{c}\text { Browse through } \\
\text { collections }\end{array}$ & - & - & - & - & - & - & - \\
\hline To read personal books & 1 & 7 & 6 & 6 & 10 & 30 & 13 \\
\hline To do assignment & 3 & 10 & 5 & 4 & 5 & 27 & 12 \\
\hline To read library books & 60 & 31 & 22 & 19 & 24 & 155 & 67 \\
\hline Total & 68 & 52 & 37 & 31 & 45 & 233 & 100 \\
\hline
\end{tabular}

Table 15: Purpose of Using the Library in Week 4

Table 15 shows that $67 \%$ of students use the library to read library books, while $6 \%$ use the library to read newspaper. $3 \%$ borrow books from the library, while 13\% read personal books for the week.

\subsection{Discussion}

The demographic data of the population shows that there are more male students than female students in the school. The school has more day students than residential students. There are more students in the Junior Secondary classes than the Senior Secondary classes.

The school has a separate building for the school library with a librarian employed. The space available for students is however limited.

The School Library has a variety of resources spanning textbooks to dictionaries and novels to Christian books. Subscription to a daily newspaper by the school assists with currency of information about regional and national issues. This will help with subjects in Commerce, Government and Social Studies.

The student attendance in the library is not affected by the day of the week or the class. There are fluctuations in attendance for each day of the week over the four weeks. The attendance of each class in the School Library was not consistent for the duration under study. The classes with the highest attendance frequency in the School Library are JS 2 and SS 2. Restrictions such as time and date should not be placed on student access to the School Library.

Students had access to a variety of resources in the School Library, but a large number only used the Library to read their class notes. The newspaper and textbooks were the most accessed and used library resources. This implies that the library resources are beneficial to classroom teaching. The school should consider purchasing more textbooks for the library. There is low patronage of faith-based materials for the duration.

Reading is the primary purpose of using the library by students. More reading spaces should be created in the library or adjoining buildings. The use of personal books, library books and newspaper during reading are important to students.

\section{Conclusion}

The School Library is important to the development of a secondary school student. All classes find the library beneficial because of the variety of materials available. There is no preference for a specific day in the week to visit the library by secondary school students. Educational organizations such as faith-based institutions should equip the School Library with subject-based materials such as textbooks. A trained librarian should be employed to manage the school library as a permanent duty.

\section{Acknowledgements}

The authors acknowledge Gbenga Ojo for editorial assistance and The Apostolic Church Model College for use of data to undertake this study.

\section{References}

i. Adebamowo, O. (2011) The Use of School Library Resources in Ogun State Secondary Schools: a study of selected secondary schools in Ijebu North L.G.A., Nigeria. Journal of Research in Education and Society, 2(1):113-121.

ii. Akande, S. O. and Bamise, O. F. (2017) The Role of School Library in Academic Motivation of Secondary School Students in Osun State, Nigeria. International Journal of Library Science, 6(1):18-27. doi: 10.5923/j.library.20170601.03

iii. Aina, L. O. (2004) Library and Information Science Text for Africa. Ibadan, Nigeria. Third World Information Service Limited.

iv. Bamidele, I. A. (2015) The Library Use Habits of Senior Secondary School Students in Ogun State, Nigeria. International Journal of Advanced Library and Information Science, 3(1):170-181. doi: 10.23953/cloud.ijalis.246

v. David-West, B. T. and Bassey, M. M. (2017) Advocacy for School Libraries in Nigeria. International Journal of Scientific Research in Education, 10(4):373-378.

vi. Daramola, C. F. (2013) Issues and Options in Selected Secondary School Libraries in Akure South Local Government Area of Ondo State, Nigeria. Journal of Education and Practice 4(12):103-109

vii. Lawal-Solarin, E. O. (2016) Investigation of School Libraries: A case study of Private School Libraries at Ado-Odo, LGA Ogun State, South West, Nigeria. Covenant Journal of Business \& Social Sciences, 7(2):15-28.

viii. Moruf, H. (2015) Students' Utilization of Secondary School Libraries in Akinyele Local Government Area of Oyo State, Nigeria. IOSR Journal of Research \& method in Education, 5(3):60-66. 
ix. Uzuegbu, C. P. and Ibiyemi, O. T. (2013) Item Community High School Library: a reflection of school libraries in Nigeria. Library Philosophy and Practice. Available at https://digitalcommons.unl.edu/libphilprac/1057

x. Zaid, Y. A. (2004) Library Development in Selected Private Secondary Schools in Lagos State. Lagos Journal of Library and Information Science Vol. 2(1): 35-44. 